\title{
WHAT TO DO ABOUT MANPOWER
}

\begin{abstract}
Ten days ago the Department of Education and Science published two reports on the supply and training of scientific and technical manpower in Britain by committees under Sir Willis Jackson and Prof. Michael Swann. The contents of these reports were summarized briefly in pages 227-8 of this journal last week. There follow solicited comments on the reports from Sir Eric Ashby, Lord Bowden, Dr. D. G. Christopherson, Sir Nevill Mott, Prof. M. Stacey and Dr. G. Templeman.
\end{abstract}

\begin{abstract}
From Sir Eric Ashby, Master of Clare College, Cambridge. THREE powerful forces influence the size and pattern of a system of higher education: (i) the pressure from students to get into it; (ii) the "suction" from employers drawing graduates out of it; and (iii) the convictions held by those within the system itself. In the United States of America the first of these three forces is the most powerful; in the Soviet Union the second is the most powerful; in Britain, until comparatively recently, the third force was the prevailing one. The Robbins Report was essentially a programme to give precedence to the first of these three forces; but we are coming to realize that we cannot afford a system of higher education based on student demand unless the system also fulfils manpower needs: the second of the three forces must play more part in the planning of higher education.
\end{abstract}

These two reports powerfully reinforce the need to allow "suction" from employers to play more part in the planning of higher education in science and technology; and paragraph 42 of the Swann Report suggests five ways in which this might be done. The doubt is whether these five ways alone would be effective. In a democracy people cannot be directed into specific employment; the Swann Report is right in saying that "the vital issue is the motivation of the individual". But it is not undemocratic to encourage motivation by inducements. For example, it has been demonstrated that the brighter school-leavers (as measured by results at A-level of G.C.E.) read science at universities in preference to technology. Are not the findings of these two reports serious enough to suggest that local authorities should offer grants to students who will read technology, and loans to all but a proportion of students who want to read science? And would it be heresy to suggest not (emphatically) that too much research is being done, but that too many young people are being encouraged to do research ? With rare exceptions, research work $\partial$ rs who never publish more than one or two papers do not make important contributions to knowledge. Long ago Lotka showed that the number of authors who publish $n$ papers is proportional to $\left(1 / n^{2}\right)$. Could the research councils, while increasing provision for systematic postgraduate studentships, restrict provision for research studentships to some reasonable value of $\left(1 / n^{2}\right)$ ?

There are other consequences for the higher education system if these two reports are to be taken seriously: defer specialization at school; make it easy (even if it involves an extra undergraduate year) for science students to switch to technology after their freshman year; establish, as an experiment, a few joint appointments between schools and universities for sixth form masters, so that they can teach in a school atmosphere and think in a university atmosphere; persuade industry that some of the money spent on advertising products would more profitably be spent on attracting talent, and that it is as important for a firm to understand its source of human raw material as it is to understand its customers; and at government level, break down the barriers, such as pension arrangements, which make migration difficult across the frontiers which separate the higher education system from government service.
From Lord Bowden, Principal, University of Manchester Institute of Science and Technology.

The Editor of Nature (October 15, p. 221) is quite right; things will never be the same again. These two reports and the Arthur Report (Enquiry into Longer-term Postgraduate Courses for Engineers and Technologists, 1964-65-H.M.S.O., 1965) will influence national policy for years to come. Why is it that so few good scientists go into industry? A famous chemical engineer told me that his company always tries to recruit some of the ablest young men of their generation. They find them, of course, in the schools of pure chemistry in the best universities. They persuade them to go and do academic research of the most esoteric kind in the best possible conditions in their industrial laboratories. After they have been working happily for a year or two someone approaches the young men in a panic and says that, important though their work is, could they help in an emergency and get a piece of plant working again? (Sometimes the firm itself has been known to sabotage the plant beforehand.)

The young men drop everything, work night and day and triumph. A gratifyingly large number of them afterwards shyly approach the management and ask if they could be allowed to transfer from pure research to the more exciting world of practical industry in future.

That this should be true has always stemed to me one of the most astonishing facts of contemporary industrial life, but as the Swann Committee has shown, young men neither understand nor appreciate the intellectual challenge of industry and many of them fear the moment of truth when their theory and their calculations will bo exposed without disguise to the ultimate test. A man may dread the possibility that if his plant blows up, he may be responsible for the death of its operators. But many men who would not shrink from responsibility are unhappy about what they regard as the frustrations of industry.

In spite of everything, many departments of engineering in English universities cannot retain enough of their own best graduates to organize adequate research schools. It has become notorious that many graduate schools could scarcely survive without forign students. Only a third of our postgraduate students of civil engineering are Englishmen. And why should English students do research work if industry values experience so much more ? A ftw years of research in some branches of modern technology can reduce a man's income significantly for the rest of his life, if he goes into industry. He only benefits from his research work if he joins the staff of a university.

W'e must preserve a balance-some good men must go into industry and others must work in universities. It will be even better if they change places occasionally.

If one classifies students as stable or neurotie, introvert or extrovert, one discovers that it is the stable extroverts who get Thirds and the unstable neuroties who tend to get Firsts.

Before we despair at the failure of our universities to provide scholarly recruits for industry, we might at least ponder the future of an industry dominated by unstable neurotics.
BowDEN 